Annals of Warsaw University of Life Sciences - SGGW

Horticulture and Landscape Architecture No 40, 2019: 3-14

(Ann. Warsaw Univ. of Life Sci. - SGGW, Horticult. Landsc. Architect. 40, 2019)

DOI 10.22630/AHLA.2019.40.1

\title{
Application of PiCUS® Sonic Tomograph 3 in studies on the cultural heritage of the Lublin region - restoration of the Eastern Orthodox church of the Dormition of the Blessed Virgin Mary in Uhrusk
}

\author{
MARGOT DUDKIEWICZ \\ Faculty of Horticulture and Landscape Architecture, University of Life Sciences in Lublin
}

\begin{abstract}
Application of PiCUS® Sonic Tomograph 3 in studies on the cultural heritage of the Lublin region - restoration of the Eastern Orthodox church of the Dormition of the Blessed Virgin Mary in Uhrusk. Uhrusk is a small town located in eastern Poland, in the Lublin region, along the border river, the Bug. The temple is situated on the outskirts of the village, on a low hill, where there was a castle founded by prince Daniel Halicki in the Middle Ages. The Orthodox church existed here before 1220, and for the first decades of its functioning it had the status of a council. Today, the existing church building was erected in 1849 as a Greek Catholic temple founded by the owner of local estate, Laura Kirsztejnowa. In 1915, the church was abandoned when the Orthodox residents of Uhrusk became refugees. In the years 1920-1927, it was renovated, due to significant losses suffered during the First World War and the Polish-Bolshevik war. The building was open again from 1920 to 1947, after which it was closed following the deportation of Orthodox Ukrainians as part of the "Wisła" Operation. At the end of the 1950 s, the Orthodox church was restored for liturgical use as a branch of the parish in Włodawa. The style of the building is defined as classicist-Byzantine with neo-Romanesque and neo-Gothic elements. In 2017, on the initiative of the Dialog Foundation in Lublin, a general renovation of the temple building and its surroundings began. Studies conducted with the use of specialized diagnostic equipment in the form of a PiCUS $\AA$ Sonic Tomograph 3 were important for the dendrological inventory. Within the boundaries of the property, 11 trees are growing, at different ages and in a healthy state. On the basis of the material collected, possible directions for the restoration of the Orthodox church's surroundings were presented.
\end{abstract}

Key words: sonic tomography, PiCUS® Sonic Tomograph 3, Uhrusk, Orthodox church

\section{INTRODUCTION}

Uhrusk is a small town located in the Lublin region, in Włodawa county, in the municipality of Wola Uhruska, nearby regional road 816 Dorohusk-Włodawa. Uhrusk, in terms of physical and geographical location, is situated in the eastern part of Polesie Lubelskie - a land with the character of a vast plain with numerous swamps, peat bogs and lakes. Small changes in the natural environment have led to this region preserving many of its natural assets. Near the village, there are forests forming part of the Sobibór Landscape Park and, at the same time, a state border with Ukraine - the Bug river. Uhrusk is the oldest commune town. The building of currently functioning Orthodox church was erected in 1849 as a Greek Catholic temple founded by the owner of the local estates, Laura Kirsztejnowa. The object is maintained in a classicist-Byzantine style with neo-Romanesque and neo-Gothic elements. The iconostasis comes from the late 19 th century, and it is supplemented by 17th and 18th centuries icons moved 
from the destroyed Orthodox church in Zbereż. This church is strongly inscribed in the history, culture and tradition of the Orthodox region. In 2017, on the initiative of the Dialog Foundation in Lublin, a general renovation of the temple building was funded from the Regional Operational Program of the Lublin Region. The surroundings of the church also require restoration preceded by in-depth interdisciplinary research. The work presents the restoration process of the dendroflora around the object applying the latest computer techniques.

The main purpose of the work is the method used to identify trees in danger of falling, thanks to the use of computer tools. Technical achievements that significantly extend the analytical and research capabilities in the reconstruction of historical objects are developing rapidly, but are being implemented very slowly in practice. When it comes to assessing trees for removal or care, most decisions are based on subjective assessments and, more rarely, invasive methods are used for this purpose. Non-invasive methods using, among others, sound waves for evaluation have been used since the beginning of the 21 st century, but they are still not widely applied. On the basis of the dendrological inventory and analysis of historical materials, a concept for restoring the surroundings of the temple was created. The research was carried out in 2017-2018.

\section{MATERIALS}

The work was carried out in two stages. The first stage of the work consisted in the analysis of source materials - old maps, iconography and inventory in archives, libraries and at the Regional Office for the Protection of Monuments in Lublin. The second stage was field research. During the field studies, the actual state of affairs and the dendrological description of 11 trees was recorded. Their basic dendrometric measurements were taken (trunk circumference, crown range and tree height) and the health condition of the trees was described in detail. Species were determined based on professional dendrological literature (Seneta and Dolatowski 2012). All work related to the measurements of objects was made using a measuring tape and a laser rangefinder. The trunk circumferences were measured to an accuracy of $1 \mathrm{~cm}$ at a height of $130 \mathrm{~cm}$ above the ground using a measuring tape. The crown projection diameter was measured using a Leica DISTO D5 Laser Rangefinder. When describing the condition of the trees, special attention was paid to the trunk health condition (possible necrosis of the trunk, cavities, rifts, traces of insect feeding, fruiting bodies of mushrooms, trunk inclination), crowns (dried branches, broken branches, asymmetry). Studies carried out with the help of specialist diagnostic equipment in the form of a PiCUS ${ }^{\circledR}$ Sonic Tomograph 3 were also important for the inventory.

The diagnostics of the tree trunks interiors using computer tomography enabled us to learn about the health status of their internal structures without the necessity of invasive drilling. The sonic tomograph has enabled the non-invasive measurement of the health condition of a tree trunk interior in terms of detecting rot, emptiness or touchwood using sound waves (Göcke et al. 2007, Brazee et al. 
2011). The complete measuring apparatus for tomographic examinations includes: central unit, sensors placed around the trunk of the tree in an amount depending on its circumference, connected to plates driven into the trunk with staples and specialized software. Sensors measure the time of sound wave propagation within the wood caused by the impact of an electronic hammer. The distances between the sensors were between 15 and $50 \mathrm{~cm}$ and were measured with the use of the PiCUS Calliper. The results, after being processed by the software, are colorful tomograms that show changes taking place inside the tree trunks. When analyzing the results obtained with the use of the tomograph, particular attention should be paid to the color scheme of the image determining the so-called wood density map. Individual colors mean different velocities of sound propagation within the trunk depending on the elasticity and density of the wood. Colors from light brown to black correspond to a range of $60-100 \%$ of the maximum speed of the sound, which means living healthy tissue. Different shades of green correspond to $40-60 \%$ of the speed of the sound, which indicates a slight deterioration in wood structure. Pink means sound propagation ranging from 20 to $40 \%$ and the color from blue to white in the range of $20-0 \%$ (the slowest speed of the sound). These are therefore the areas with the weakest structure, where damage and intense wood decay are taking place (Chomicz 2007, 2010). Yellow lines on the trunk cross-section suggest the occurrence of internal cracks, which are extremely dangerous due to the fact that there are often no obvious external symptoms that could confirm this. The thicker the line, the greater the risk of such a situation. Meanwhile, the red line on the tomogram shows the boundary wall thickness, which makes it possible to set a limit on the minimum mechanical strength of the tree trunk. Such data are helpful in calculating the so-called $t / R$ coefficient, i.e. the ratio of healthy wood $(t)$ to the radius of the tree trunk $(R)$. According to the available literature, the $t / R$ ratio should not be lower than 0.33 and, for trees with hidden cavities, even 0.3 (Kane et al. 2001, Hayes 2002, Suchocka 2012, Mattheck et al. 2015). All values below this limit increase the risk of the tree breaking unexpectedly. The risk increases even more when the trunk's interior is infected by fungal pathogens.

The age of trees is estimated and we should not be misled by excessive disparities. This can be influenced by many factors (environmental conditions, soil fertility, soil moisture, growth rate or genetic factors), therefore plantings from the same period may vary considerably in age range (Szczepanowska et al. 2010, Mydłowska 2014).

On the basis of the dendrological inventory and analysis of historical materials, the concept for the restoration of the garden around the temple was created.

\section{RESULTS}

\section{Historical outline of the object}

Chronicle sources from 1204 provide information about the town that was given to Prince Aleksander Wsiewłodowicz. In the Hipacowska chronicle from 1218, there is a note that the castle was extended by the Prince of Halych, Daniel Romanowicz. At that time, a monastery 
of Saint Elijah and a Cathedral Orthodox church of the Blessed Virgin Mary were erected. At the same time, Prince Daniel established the Uhrusk diocese, the first bishop of which was a Greek priest named Azaf. In this way, Uhrusk became the capital of the Vladimir-Halych principality at the time, as the prince moved his headquarters here from distant Halych. Around 1240, Daniel transferred the capital of the duchy and the seat of the eparchy to Chełm, which contributed to the decline of Uhrusk's importance (Mironowicz 2011). In the 13th and 14th centuries, Uhrusk was the property of the Vladimir-Halych princes from the Romanowicz dynasty. After incorporating Chełm Land into the Kingdom of Poland in 1366, Uhrusk became the king's property, which Władysław Jagiełło gave to the Boyar of Olechno (Aleksandr) Dymitrowicz "Biały" in 1414. In the 17th and 18 th centuries, the owners of Uhrusk were, among others, the Krzywczyckis, the Dłużewskis, the Ledóchowskis. In the 17th century, the Orthodox parish together with the entire Orthodox Chełm eparchy became part of the structures of the Uniate (Greek Catholic) church. In 1875, the Russian partitioning powers liquidated the Uniate Chełm eparchy and forcibly incorporated it into the structures of the Orthodox Church. The classical Orthodox church of the Dormition of the Blessed Virgin Mary in Uhrusk, owned by the parish of the Nativity of the Blessed Virgin Mary in Włodawa, was founded in 1849 as a Uniate Orthodox Church. Next to the church, the remains of the cemetery have been preserved. In 1822, General Henryk Ignacy Kamieński bought and consolidated the Uhrusk property, which he then passed on to his son, Henryk Kamieński. In 1852, Henryk Kamieński gave Uhrusk to his sister Laura Suffczyńska. The next owners of Uhrusk were: Jan Rusiecki, Henryka from the Rusieckis Izbińska, Leonard Ruszkowski and Leon Matuszewski. In 1881, the property was purchased by Mieczysław Niemirycz, whose son Stanisław was (until 1944) the last successor of Uhrusk.

As already mentioned, the first Orthodox church in Uhrusk was erected around 1220. Another Orthodox temple in Uhrusk was founded before 1429. The third church was built in 1785 from the foundation of Barbara Noskowska. It was a wooden building (Brykowski and Smulikowska 1975, Pelica 2009). The building of the currently functioning church was erected in 1849 as a Greek Catholic temple founded by the owner of the local estates, Laura Kirsztejnowa. The building was built in the vicinity of the older church, but during the construction of the new one, the older building was demolished, due to its poor technical condition. The building became the property of the Russian Orthodox Church after liquidation of the Uniate Chełm diocese in 1875. As part of the interior adaptation to the requirements of the Orthodox liturgy, two side altars of the temple were juxtaposed to create an iconostasis. Probably at the same time, the tower-belfry was added to the building (1893 at the latest). In 1907, after the general renovation of the building and the restoration of its structure, the church was re-consecrated (Cynalewska-Kuczma 2004).

In 1915, the Orthodox inhabitants of Uhrusk decided to become refugees. The Orthodox church was abandoned and in the same year it was seriously dev- 
astated. The following year, it suffered additional losses due to fire, and during the Polish-Bolshevik war of 1920, it was devastated once again. Then in 1920, the temple was reactivated and became the seat of the Orthodox parish. In the years 1920-1927, it was renovated (Cynalewska-Kuczma 2004, Pelica 2009).

In 1944, the church was damaged during military operations. After the end of the Second World War and the displacement of the Ukrainian population to the USSR and Kosyń, 252 people of the Orthodox religion remained. In the same year, as part of the "Wisła" Operation, almost all Orthodox inhabitants were deported from Uhrusk, and the parish suspended its activities. According to some sources, the church was reopened in 1957, according to others it happened the following year. The state authorities then expressed their consent to the opening of two new Orthodox churches in the Lublin region - in Zamość and in Uhrusk. In the case of the Uhrusk church, this meant its parish was subordinated to Włodawa. The state authorities agreed to open both temples because the hierarchs of the Polish Autocephalous Orthodox Church argued that its functioning would enable missionary activity among Greek Catholics. The closed church - during the period when it was not used by followers - was looked after by the Catholic Church. After opening the building, it turned out that valuable elements of its fittings had been stolen or destroyed. Therefore, some elements of the fittings of Saint George's Orthodox church in Zbereż, which was destroyed in 1938, were moved to the church. According to another source, this happened in 1960. Six years later, the entire iconostasis of the Uhrusk church was restored (Wysocki 2011). The church is now entered in the register of monuments as number A/133/39.

\section{Architecture of the building and interior design}

The Orthodox church in Uhrusk was erected on a longitudinal plan, and after the construction of the tower, it became a three-part building. The nave of the temple - was built on a rectangular plan and covered with a gable roof. The threepart presbytery (with two sacristies) is simply closed and also covered with a gable roof. The tower-belfry of the church is built on a square plan, and rises above the vestibule. The belfry is covered with a multi-layered roof, covered with sheet metal. The style of the building is defined as classicist-Byzantine with neo-Romanesque and neo-Gothic elements (Brykowski and Smulikowska 1975).

Against the background of Uniate temples erected in the Lublin region in the same period, the Uhrusk Orthodox church is distinguished by decorative architectural details. On the belfry, the frieze passes into the triangular end of the façade; a similar motif is used in the modest neo-Romanesque portal adorning the entrance to the temple. The portal is made up of two Tuscan pilasters and a semicircular archivolt. The windows of the building are arched, except for the rectangular window in the altar room. The fact that the Orthodox church in Uhrusk never became a Roman Catholic church (unlike many other Eastern Christian churches in the region) makes it possible to draw conclusions about the original appearance of Uniate nineteenth-century churches in the Lublin re- 
gion and the way they were rebuilt after the change of religion to the Orthodox (Cynalewska-Kuczma 2004).

The iconostasis in the Uhrusk church has elements, that most probably come from the older church in this town, was made in the 18th century. In the finial, there are icons of saints John, Mark and Matthew. The temple is also fitted with three antique Uniate icons: eighteenth-century images of the Virgin Mary and Saint Nicholas (folk painting with features of the Baroque style) and an older seventeenth-century icon of the Virgin Mary. In the church, there is also a feretory with the figures of the Archangel Michael and the Virgin Mary (modeled on the icon of the Virgin Mary in Chełm). There is also a pacific made of brass depicting Jesus crucified against a background of the view of Jerusalem and the figure of God the Father in the finial. On the reverse of the pacific, there was the date of completion and an inscription of unknown content, both illegible (Brykowski and Smulikowska 1975).

\section{Inventory of the surroundings}

In 2017, the building of the temple was under renovation (Figs. 1, 2). The area of the plot is partially fenced - from the main street side there is a gate and a brick fence. Around the temple, the former Orthodox church cemetery is located, with one preserved gravestone in the south-eastern part of the plot. There are 11 trees growing within the property's boundaries, of different ages and health status.

In total, 11 trees were documented on the site, among which the following dominate: common ash (Fraxinus excel-

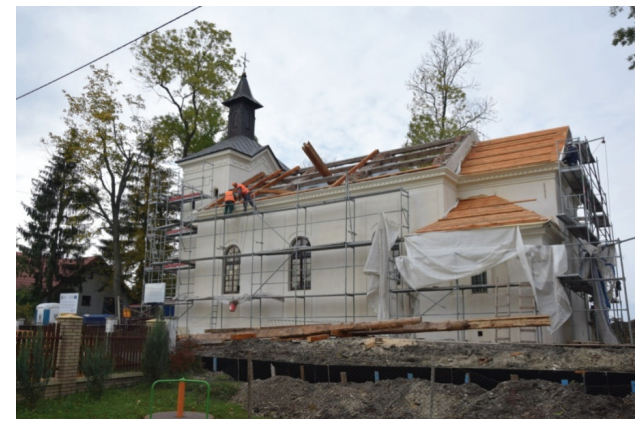

FIGURE 1. View of the south facade of the Orthodox church (photo by M. Dudkiewicz, 2017)

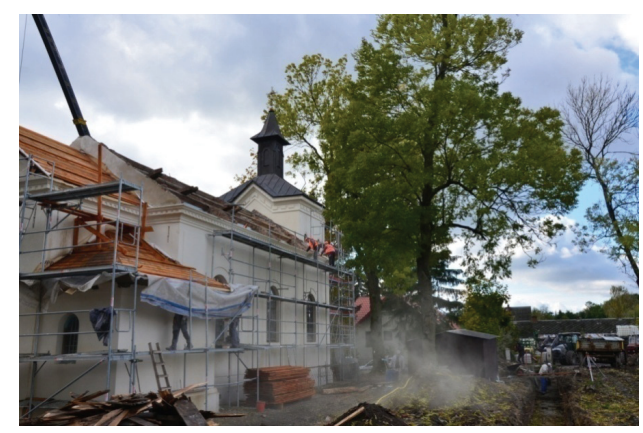

FIGURE 2. View of the east facade of the Orthodox church (photo by M. Dudkiewicz, 2017)

sior L.) and small-leaved linden (Tilia cordata Mill.). In addition to the above there are also: Norway maple (Acer platanoides L.), horse-chestnut (Aesculus hippocastanum L.) and common pear (Pyrus communis L.). Among them, there are self-seedings and those that were planted without an accepted composition, on the borders of the plot.

The management plan for the tree stands assumes the removal of three trees for sanitary and investment reasons. Correction and sanitary cutting of branches should include all other trees. In the case of one ash specimen, the use of elastic tapes is suggested. Selected tree tomograms are shown in Table 2. 
TABLE 1. Species and quantitative list of trees in the area of study

\begin{tabular}{|l|c|c|}
\hline Latin name & English name & Quantity (pcs) \\
\hline Acer platanoides L. & Norway maple & 1 \\
\hline Aesculus hippocastanum L. & horse-chestnut & 6 \\
\hline Fraxinus excelsior L. & common ash & 1 \\
\hline Pyrus communis L. & common pear & 2 \\
\hline Tilia cordata Mill. & small-leaved linden & \\
\hline
\end{tabular}

TABLE 2. Results of a detailed dendrological inventory of selected tree specimens

\begin{tabular}{|c|c|c|}
\hline Name & Notes / health condition & Instructions \\
\hline 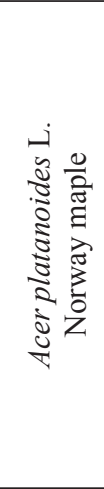 & $\begin{array}{l}\text { circumference of the trunk at a height of } 1.3 \mathrm{~m}: 155 \mathrm{~cm} \\
\text { height: } 13.6 \mathrm{~m} \\
\text { range of the crown: } 10 \mathrm{~m} \\
\text { approximate age: } 88 \text { years } \\
\text { Sparse, tall crown, with numerous branch breaks. Foci of mistle- } \\
\text { toe. A lot of branch deadwood } 60 \% \text {. Trunk leans } 5 \% \text { towards } \\
\text { the west. Small swelling caused by scars and traces of cracks on } \\
\text { the trunk. Crown extended to the west with damaged top (bro- } \\
\text { ken guide). In the boughs, protruding bark and tissue necro- } \\
\text { sis with numerous traces of insect feeding. Wood with slightly } \\
\text { weakened structure and the beginning of destruction occupies the } \\
\text { core part of the trunk }(21 \times 12.5 \mathrm{~cm}) \text {. Health condition - poor. }\end{array}$ & $\begin{array}{l}\text { To be removed for } \\
\text { sanitary reasons and } \\
\text { high risk of the trunk } \\
\text { breaking due to its } \\
\text { low } t / R \text { ratio }- \text { be- } \\
\text { low the safe limit. }\end{array}$ \\
\hline 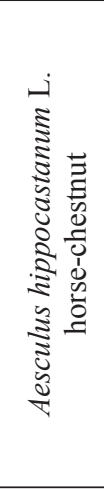 & $\begin{array}{l}\text { circumference of the trunk at a height of } 1.3 \mathrm{~m}: 145 \mathrm{~cm} \\
\text { height: } 11 \mathrm{~m} \\
\text { range of the crown: } 8 \mathrm{~m} \\
\text { approximate age: } 49 \text { years } \\
\text { Crown extended to the west. The beginning of the crown at a height } \\
\text { of } 4 \mathrm{~m} \text {. Large branch deadwood ( } 30 \% \text { ). The stem is divided into } \\
\text { two guides on a height of } 3 \mathrm{~m} \text {. U-shaped fork. Guide from the so- } \\
\text { uth with broken tip. Numerous hollows created by broken branches. } \\
\text { Small abrasions of the bark. Slight puffiness on the trunk. Visible } \\
\text { symptoms of feeding by chestnut stag beetle (Cameraria ohri- } \\
\text { della). The inside of the trunk at the measurement height in very } \\
\text { good condition. General condition of the tree on an average level. }\end{array}$ & $\begin{array}{l}\text { Removal of dead- } \\
\text { wood; sanitary cut- } \\
\text { ting; slight correc- } \\
\text { tion of the crown. } \\
\text { Raking and burning } \\
\text { of autumn leaves to } \\
\text { combat pests; during } \\
\text { the growing season, } \\
\text { the use of phero- } \\
\text { mone or sticky traps. }\end{array}$ \\
\hline 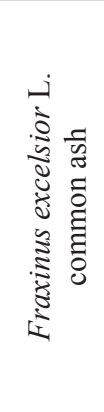 & $\begin{array}{l}\text { circumference of the trunk at a height of } 1.3 \mathrm{~m}: 185 \mathrm{~cm} \\
\text { height: } 21 \mathrm{~m} \\
\text { range of the crown: } 7 \mathrm{~m} \\
\text { approximate age: } 98 \text { years } \\
\text { High crown. Trunk branching into two guides at a height of } 10 \mathrm{~m} \text {. } \\
\text { U-shaped fork. From the east place on the cut branch at a height } \\
\text { of } 5 \mathrm{~m} \text { with no clear signs of scarring on the edges of the wound. } \\
\text { Numerous frost bars. From the base of the trunk to a height of } 3.5 \mathrm{~m} \text {, } \\
\text { necrosis with well-developed callus tissue around the edges. Depar- } \\
\text { ting patches of bark from the east revealing wood }(200 \times 30 \mathrm{~cm}) \text {. }\end{array}$ & $\begin{array}{l}\text { Indicated strength- } \\
\text { ening of guides with } \\
\text { elastic tapes; protec- } \\
\text { tion against infection } \\
\text { of exposed wood lay- } \\
\text { ers, sanitary cutting. }\end{array}$ \\
\hline
\end{tabular}


TABLE 2 cont.

\begin{tabular}{|c|c|c|}
\hline Name & Notes / health condition & Instructions \\
\hline 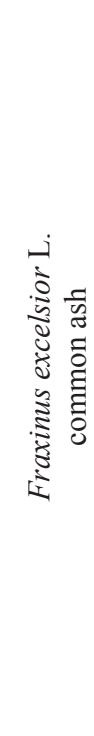 & $\begin{array}{l}\text { circumference of the trunk at a height of } 1.3 \mathrm{~m}: 180 \mathrm{~cm} \\
\text { height: } 23 \mathrm{~m} \\
\text { range of the crown: } 7 \mathrm{~m} \\
\text { approximate age: } 95 \text { years } \\
\text { One-sided crown, directed to the east, which may adversely impact } \\
\text { the stability of the tree due to the shift of the center of gravity. Bro- } \\
\text { ken branches at different heights from the west side. Numerous ju- } \\
\text { venile shoots (so-called wolves). Dried branches, about } 20 \% \text {. The } \\
\text { tree grows on the border of the plot on a small hill. Numerous swel- } \\
\text { lings on the trunk and a large number of broken branches. Interfe- } \\
\text { res with the planned construction of the fence. At the base of the } \\
\text { trunk, a cavity reaching } 20 \mathrm{~cm} \text { into the trunk } 30 \times 30 \mathrm{~cm} \text {. In the hol- } \\
\text { lows on both sides of the trunk, visible fruiting bodies of fungi. At } \\
\text { a height of } 1.7 \mathrm{~m} \text {, a broken branch with a hollow on scarred edges. } \\
\text { Outbreaks of wood with a weakened structure and with advanced on- } \\
\text { set of decomposition are located to the east side of the trunk interior } \\
(26 \times 34 \text { and } 16 \times 10 \mathrm{~cm}) \text { at a height of } 50 \mathrm{~cm} \text { from the ground sur- } \\
\text { face. The overall health condition of the tree is just reasonable, de- } \\
\text { spite the relatively high mechanical strength of the trunk }(t / R=0.34) \text {. }\end{array}$ & $\begin{array}{l}\text { To be felled due to } \\
\text { its interfering with } \\
\text { a planned fence. }\end{array}$ \\
\hline
\end{tabular}

\section{Design concept}

In the case of greenery restoration in the area of a historic sacral building, the basic principle of the study should be to refer to the historical selection of species in such facilities and planning plantings in accordance with the principles of religious symbolism (Baldock 1994, Misiak 2010, Szcześniak 2014, Szary 2015, Kujawska and Łuczaj 2016).

Formerly, the location of temples was not accidental. The main rule in erecting a church was locating it in a place marked by miracle, revelation or ardent faith of the followers. Buildings were also harmoniously integrated into nature. Today, the surroundings of the old Orthodox churches are often the last refuge for old, tall trees. Among numerous, contemporary transformations of the country landscape, the old temples surrounded by greenery remind us of our quest for harmony with the world. The arrangement of the church's surroundings in Uhrusk mainly includes the following colors: blue (the main color in the interior of the temple), green, white and brown. The blue color symbolizes the sky; it also signifies hope and the mystery of being. Green is the color of spring and rebirth. In iconography, green is the herald of the Holy Spirit and the color of John the Evangelist as well as many prophets. The white color in symbolism of the Orthodox church means God's revelation and glory. White is an expression of joy and festive mood; it also symbolizes purity, innocence, God's wisdom, joy and happiness. The color brown symbolizes the material world, humility and poverty (Uścinowicz 1997, Keczyński and Keczyńska 1999, Kępkowicz and Gawryluk 2009).

An important criterion in the selection of plantings was religious and folk 
symbolism, aesthetic values and resistance to frost. The project assumes planting uniform, compact groups of plants that provide the best decorative effects during seasonal flowering.

The project involves the introduction of new trees, shrubs and perennials that increase the attractiveness of the property as well as highlighting its sacral character. This vegetation is to supplement and enrich the existing stand. Closer to the church, nobler plants, i.e. boxwood evergreen, 'Nostalgia' rose and 'Little Lime' bouquet hydrangea will be introduced. A hedge of cut boxwood is planned near the entrance in the southern part of the area. Symmetrically, a similar flowerbed with boxwood borders will be located behind the church building. It was decided to use hedges to emphasize the layout of the compositional and aesthetic frame of the building. In the hedge, we propose creating larger, rhythmic spherical forms. Along the side walls of the church, boxwood passes into flowerbeds shaped like mandorlas (almonds). White and red roses and/or white hydrangeas are planned inside. In front of the entrance to the temple, a column of decorative cherry is proposed. Due to the old graves, large plantings of periwinkle are planned to provide cover. This will facilitate the maintenance of the property and reduce the area of lawns that would have to be mown regularly. It is also planned to introduce the 'Krossa Regal' funkia and ferns - ostrich plume. The plot from the north side will be protected by a low variety of lime. Also on the south side of the plot, there will be symmetrical tree plantings. In the lawn, planting single-color, large groups of crocuses is proposed. A strong red accent will be pro- vided by the rather large, red-leaved tree in the south-east part of the property.

The area will be fitted with two benches with backrests, a rubbish bin and an information board presenting the history of this Orthodox church. All elements will be in the appropriate color, thus ensuring the area is aesthetically coherent.

The concept of the garden meets the needs of its contemporary users: clergy, followers and tourists. The plant species proposed create a composition emphasizing the seriousness of the place, as well as being suited to the habitat (stand, exhibition) and compatible with the landscape (Figs. 3, 4).

\section{SUMMARY}

The main assumption of the study was to examine the efficiency of the use and potential of sonic tomography in the restoration of a garden in a sacral area. The need for such research results from the need of Polish conservators and landscape architects for new methods and tools supporting spatial shaping. The research confirmed the legitimacy of the application of the chosen method and the accurate selection of tools suitable for researching cultural heritage. The collected data formed the basis for information on the stand stock and served as the basis for the development of the Orthodox church's surrounding design.

The safety of persons and property in the area where the historic tree stand is growing is very important and requires the use of precise techniques to detect wood decay and other types of structural defects inside tree trunks. In the 


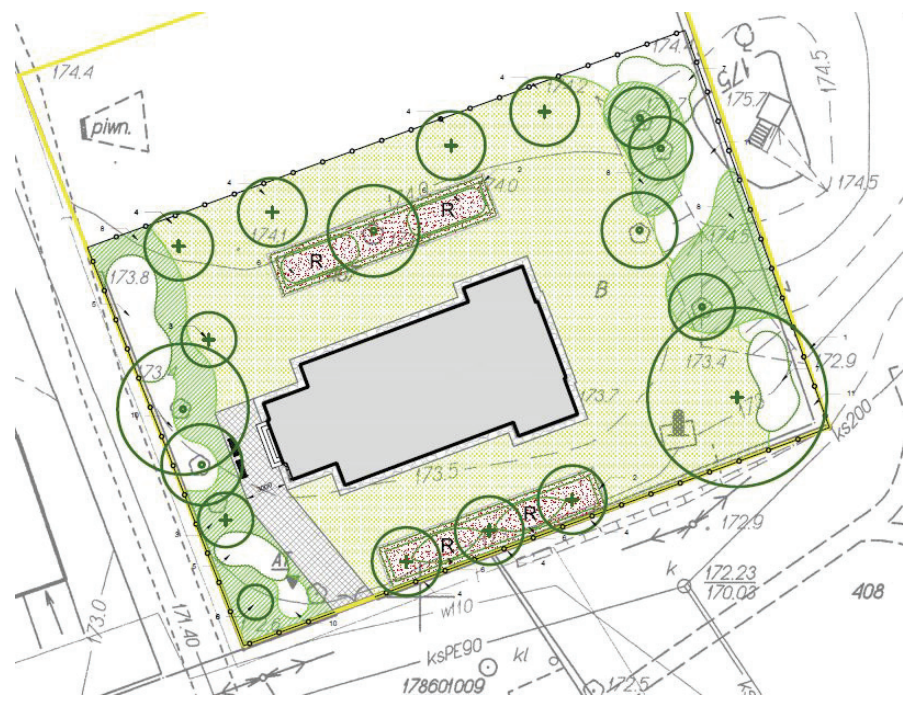

FIGURE 3. Design of greenery around the Orthodox church in Uhrusk - projection from above (developed by M. Dudkiewicz)

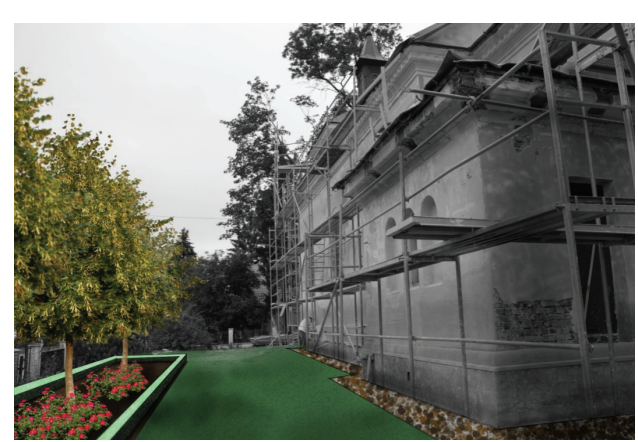

FIGURE 4. Design of greenery around the Orthodox church in Uhrusk - visualization (developed by M. Dudkiewicz)

area covered by the dendrological inventory, 11 trees were located, among which highland ashes and small-leaved limes were predominant. The trees seriously threatened the church building, parishioners and tourists. Thanks to the use of sound tomography, the threats were quickly diagnosed and restoration work was carried out.

\section{Acknowledgements}

Research financed from the statutory funds of the Department of Landscape Architecture.

\section{REFERENCES}

BALDOCK J. 1994: Symbolika chrześcijańska [Christian symbolism]. Rebis, Poznań.

BRAZEE N.J., MARRA R., GÖCKE L., Van WASSENAER P. 2011: Non-destructive assessment of internal decay in three hardwood species of northeastern North America Rusing sonic and electrical impedance tomography. Forestry 84 (1): 33-39.

BRYKOWSKI R., SMULIKOWSKA E. (Eds.) 1975: Katalog zabytków sztuki w Polsce. Województwo lubelskie, powiat włodawski [Catalog of art monuments in Poland. Lublin voivodship, Włodawa poviat]. Instytut Sztuki Polskiej Akademii Nauk, Warszawa.

CHOMICZ E. 2007: Bezinwazyjne metody wykrywania defektów wewnątrz pni 
drzew stojących (Tomograf PiCUS ${ }^{\circledR}$ Sonic i PiCUS ${ }^{\circledR}$ Treetronic) [Non-invasive methods for detecting defects inside standing tree trunks (Tomograf PiCUS ${ }^{\circledR}$ Sonic and PiCUS® Treetronic)]. Leś. Pr. Bad. 3: 117-121.

CHOMICZ E. 2010: Bezinwazyjne diagnozowanie kondycji drzew zabytkowych $\mathrm{z}$ zastosowaniem tomografów PiCUS $\AA$ [Non-invasive diagnosis of the condition of historic trees using tomographs PiCUS $₫$ ]. Kurier Konserwatorski 8: 29-32.

CYNALEWSKA-KUCZMA P. 2004: Architektura cerkiewna Królestwa Polskiego narzędziem integracji z Imperium Rosyjskim [Church architecture of the Kingdom of Poland as a tool of integration with the Russian Empire]. Wydawnictwo Naukowe UAM, Poznań.

GÖCKE L., RUST S., WEIHS U., GÜNTHER T., RÜCKER C. 2007: Combining Sonic and Electrical Impedance Tomography for the Nondestructive Testing of Trees. In: Proceedings of the 15th International Symposium on Nondestructive Testing of Wood. 10-12.09.2007 Duluth, Minnesota: $31-42$.

HAYES E. 2002: Tree Risk Assessment \& Tree Mechanics. Arborist News 6 (11): 33-39.

KANE B., RYAN D., BLONIARZ D.V. 2001: Comparing formula that assess strength lossdue to decay in trees. J. Arboric. 27 (2): 78-87.

KECZYŃSKI E., KECZYŃSKA A. 1999: Drewniane cerkwie białostocczyzny [Wooden churches of Białystok region]. Związek Białoruski w RP, Białystok - Białowieża.

KĘPKOWICZ A., GAWRYLUK A. 2009: Zieleń w otoczeniu współczesnej cerkwi, koncepcja projektowa w Bielsku Podlaskim [Greenery in the surroundings of a modern church, design concept in Bielsk Podlaski]. Architektura Krajobrazu 1: 54-58.

KUJAWSKA M., ŁUCZAJ Ł. 2016: Rośliny w wierzeniach i zwyczajach ludowych
[Plants in folk beliefs and customs]. Polskie Towarzystwo Ludoznawcze, Wrocław.

MATTHECK C., BETHGE K., WEBER K. 2015: The body language of trees. In: Encyclopedia of Visual Tree Assessment. Karlsruhe Institute of Technology - Campus North, Karlsruhe: 404-405.

MIRONOWICZ A. 2011: Biskupstwo turowsko-pińskie w XI-XVI wieku [The Turin-Pinsk bishopric in the 11th-16th centuries]. Trans Humana, Białystok.

MISIAK T. 2010: Magiczne drzewa w dziejach, legendach i środowisku nad środkowym Sanem [Magic trees in history, legends and the environment above central San]. Podkarpacki Instytut Książki i Marketingu, Rzeszów.

MYDŁOWSKA A. 2014: Ochrona zieleni $\mathrm{w}$ procesie inwestycyjnym $\mathrm{z}$ uwzględnieniem wiedzy dendrologicznej. Załącznik do materiałów szkoleniowych pt. Wizualna diagnoza drzew zagrażających bezpieczeństwu - metody i sposoby usprawniające kontrolę drzewostanu miejskiego [Greenery protection in the investment process, taking into account dendrological knowledge. Annex to the training materials Visual diagnosis of trees threatening security - methods and methods to improve the control of urban stands]. Dendros, 20-21.11.2014 Poznań.

PELICA G.J. 2009: Dzieje parafii Zaśnięcia Matki Bożej w Uhrusku [History of the Dormition of the Mother of God parish in Uhrusk]. Wiadomości Polskiego Autokefalicznego Kościoła Prawosławnego 2 (231).

SENETA W., DOLATOWSKI J. 2012: Dendrologia [Dendrology]. Wydawnictwo Naukowe PWN, Warszawa.

SUCHOCKA M. 2012: Zalety i ograniczenia stosowania wizualnej metody oceny drzew (VTA) jako odpowiedź na problemy związane z zagrożeniami powodowanymi przez drzewa miejskie [Advantages and limitations of Visual Tree Assessment (VTA) method application as a response to the 
hazard related problems caused by trees]. Człowiek i Środowisko 36 (1-2): 97-110.

SZARY A. 2015: Bieszczadzkie motywy roślinne. Między światem żywych a krainą umarłych [Bieszczady floral motifs. Between the world of the living and the land of the dead]. Carpathia, Rzeszów.

SZCZEPANOWSKA H., OLIZAR J., BOROWSKI J., SITARSKI M., SUCHOCKA M., SZADKOWSKA E. 2010: Synteza pracy opracowanie nowej metody określania wartości drzew wraz ze współczynnikami różnicującymi oraz merytorycznym uzasadnieniem metody i zasadnością jej wprowadzenia do obiegu prawnego [Work synthesis, developing a new method for determining the value of trees together with differentiating factors and substantive justification for the method and the legitimacy of its introduction into legal circulation]. IGPiM, Warszawa.

SZCZEŚNIAK K. 2013: Świat roślin światem ludzi na pograniczu wschodniej i zachodniej Słowiańszczyzny [The world of plants - the world of people on the border between Eastern and Western Slavic]. Wydawnictwo UG, Gdańsk.

UŚCINOWICZ J. 1997: Symbol, archetyp, struktura, hermeneutyka tradycji w architekturze świątyni ortodoksyjnej [Symbol, archetype, structure, hermeneutics of tradition in the architecture of the Orthodox temple]. Wydawnictwo PB, Białystok.

WYSOCKI J. 2011: Ukraińcy na Lubelszczyźnie w latach 1944-1956 [Ukrainians in the Lublin region in 1944-1956]. Instytut Pamięci Narodowej, Lublin.

Streszczenie: Zastosowanie PiCUS ${ }^{\circledR} \quad$ Sonic Tomograph $3 w$ badaniach dziedzictwa Lubelszczyzny - rewaloryzacja cerkwi pw. Zaśnięcia Najświętszej Maryi Panny w Uhrusku. Uhrusk jest to niewielka miejscowość położona w województwie lubelskim. Świątynia usytuowana jest na obrzeżach wsi, na niskim wzniesieniu, na któ- rym w średniowieczu znajdował się gród założony przez Daniela Halickiego. Cerkiew istniała tu przed 1220 rokiem i przez pierwsze dekady funkcjonowania miała status soboru. Budynek obecnie funkcjonującej cerkwi został wzniesiony w 1849 roku jako świątynia greckokatolicka, z fundacji właścicielki miejscowych dóbr Laury Kirsztejnowej. W 1915 roku cerkiew została porzucona, gdy prawosławni mieszkańcy Uhruska udali się na wygnanie. W latach 1920-1927 była remontowana w związku ze znacznymi stratami, jakie poniosła w czasie pierwszej wojny światowej i wojny polsko-bolszewickiej. Obiekt był ponownie czynny w latach 1920-1947, gdy został zamknięty po wywózkach prawosławnych Ukraińców w ramach akcji „Wisła”. Pod koniec lat pięćdziesiątych cerkiew przywrócono do użytku liturgicznego jako filię parafii we Włodawie. Styl budowli określa się jako klasycystyczno-bizantyjski z elementami neoromańskimi i neogotyckimi. W 2017 roku z inicjatywy lubelskiej Fundacji Dialog rozpoczęto remont generalny świątyni i jej otoczenia. Badania prowadzono w latach 2016-2017. Istotne w inwentaryzacji dendrologicznej było zastosowanie specjalistycznej aparatury diagnostycznej - PiCUS® Sonic Tomograph 3. Łącznie na terenie opracowania zinwentaryzowano 11 drzew w różnym wieku i stanie zdrowotnym. Na podstawie zebranego materiału przedstawiono kierunki rewaloryzacji otoczenia cerkwi.

Slowa kluczowe: tomografia dźwiękowa, PiCUS ${ }^{\circledR}$ Sonic Tomograph 3, Uhrusk, cerkiew

MS received: 06.11.2018

MS accepted: 19.10.2019

Author's address:

Margot Dudkiewicz

(https://orcid.org/0000-0002-3762-6192)

Wydział Ogrodnictwa i Architektury Krajobrazu

Uniwersytet Przyrodniczy w Lublinie

ul. Głęboka 28, 20-612 Lublin

Poland

e-mail: margotdudkiewicz@o2.pl 